\title{
Znaczenie kontekstu sytuacyjnego w lokalnej polityce publicznej
}

DOI: $10.19195 / 1643-0328.21 .8$

Słowa kluczowe: gmina, lokalna polityka publiczna, kontekst sytuacyjny, planowanie polityki publicznej

\section{Wprowadzenie}

Coraz większa złożoność interwencji podejmowanych przez podmioty publiczne powoduje konieczność uwzględniania wielu uwarunkowań, które mają wpływ na uzyskiwane efekty. Zaspokajanie różnorodnych i ciągle rosnących potrzeb społecznych realizowane jest $\mathrm{w}$ ramach polityki publicznej, będącej z kolei zbiorem wielu polityk sektorowych, zwanych również szczegółowymi. Wysoki stopień skomplikowania środowiska realizacji polityk publicznych w połączeniu ze wzrostem oczekiwań społecznych wobec państwa powoduje, że władze centralne i administracja rządowa nie są w stanie sprostać wyzwaniom samodzielnie. Realizacja polityki publicznej musi się odbywać na wielu poziomach władzy.

Istotną rolę odgrywają tu samorządy terytorialne, zwłaszcza gminy, którym w ramach decentralizacji państwa przekazano wykonywanie istotnej części zadań publicznych, szczególnie tych, które dotykają obywateli w sposób bezpośredni i zaspokajają ich podstawowe potrzeby zbiorowe. Powinno się to odbywać „poprzez podejmowanie planowych, zracjonalizowanych działań, projektowanych i wykonywanych w oparciu o obiektywne przesłanki i ich analizę. Ten modelowy sposób angażowania się samorządów terytorialnych w rozwiązywanie problemów i dostarczanie określonych usług wy-

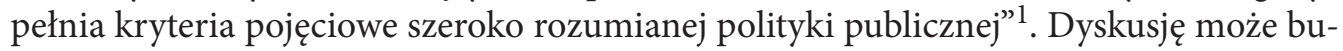
dzić zakres samodzielności, jaką dysponują samorządy terytorialne. Czy samodzielność ta, zarówno w wymiarze prawno-ustrojowym, ekonomicznym, jak i organizacyjnym, jest na tyle duża, że można mówić o warunkach do prowadzenia lokalnej/regionalnej polityki publicznej?

${ }^{1}$ B. Kotarba, The implementation of public policies by the local govermnments: education policy, [w:] New Public Governance in the Visegrád Group (V4), red. R. Wiszniowski, K. Glinka, Toruń 2015, s. 187. 
Nie wdając się w szczegółowe analizy, można stwierdzić, że największym zakresem samodzielności prawnoustrojowej dysponują gminy. Wynika to z przepisów Konstytucji RP i ustawy ustrojowej ${ }^{2}$. W zakresie samodzielności organizacyjnej samorządy terytorialne mogą określać, w granicach ustaw, swój ustrój wewnętrzny oraz powoływać jednostki organizacyjne, za pomocą których realizują zadania ${ }^{3}$, lub też zlecać wykonywanie zadań podmiotom zewnętrznym ${ }^{4}$. Konstytucja gwarantuje jednostkom samorzą$\mathrm{du}$ terytorialnego udział $\mathrm{w}$ dochodach publicznych, odpowiedni do przypadających im zadań. Źródłami dochodów są dochody własne, subwencje i dotacje celowe z budżetu państwa (art. 167). Szczegółowe rozwiązania zawarto w ustawie o dochodach samorządu terytorialnego ${ }^{5}$. Chociaż samodzielność gmin (również powiatów i województw samorządowych) nie jest samoistna i nieograniczona, to jednak zasygnalizowane w ujęciu normatywnym warunki funkcjonowania samorządu gminnego wskazują, że może on być podmiotem realizującym „własną" politykę publiczną (chociaż musi/powinna ona być zgodna z polityką państwa).

Ważną kwestią jest, czy aktywni aktorzy szeroko rozumianej sfery publicznej mają świadomość, że uczestniczą w realizacji polityki publicznej. Jest to o tyle istotne, że brak tej świadomości przekłada się na jakość polityki, gdyż wyklucza, lub czyni przypadkowym, wykorzystanie rozwiązań bazujących na sprawdzonych doświadczeniach i osiągnięciach, w tym dostępnej wiedzy naukowej i eksperckiej.

Życie publiczne w Polsce nabrało cech, które nie sprzyjają profesjonalizacji uprawiania polityki publicznej. Spolaryzowanie społeczeństwa, w tym partii politycznych, które są pochłonięte sporami w dużej mierze o charakterze ideologicznym i historycznym, brak wypracowanych metod ewaluacji podejmowanych działań, nikłe zaangażowanie ekspertów oraz słabe relacje praktyków z ośrodkami naukowymi wpływają na jej niską jakość ${ }^{6}$ W takich warunkach badanie polityki publicznej ma szczególne znaczenie. Ma nie tylko wymiar czysto naukowy, teoretyczny, lecz może także przyczynić się do wzro-

2 W Konstytucji Rzeczypospolitej Polskiej z dnia 2 kwietnia 1997 r. (Dz.U. Nr 78, poz. 483 z późn. zm.) jest mowa o sądowej ochronie samodzielności jednostek samorządu terytorialnego (art. 165 ust. 2), w ustawie zaś z dnia 8 marca 1990 r. o samorządzie gminnym (u.s.g.) (tekst jedn. Dz.U. z 2016 r. poz. 446) zapisano wprost sądową ochronę samodzielności gminy (art. 2 ust. 3). Ponadto samorządy terytorialne mają osobowość prawną (art. 165 ust. 1 Konstytucji RP oraz art. 2 ust. 2 u.s.g.), a istotną część zadań publicznych wykonują „w imieniu własnym i na własną odpowiedzialność” (art. 16 Konstytucji RP, art. 2 ust. 1 u.s.g.).

3 Art. 169 ust. 4 Konstytucji RP oraz art. 3 u.s.g. Dopuszczalne formy organizacyjno-prawne jednostek organizacyjnych reguluje ustawa z dnia 29 sierpnia 2009 r. o finansach publicznych, tekst jednolity Dz.U. z 2013 r. poz. 885.

4 Art. 9 u.s.g.

5 Ustawa z dnia 13 listopada 2003 r. o dochodach jednostek samorządu terytorialnego, tekst jednolity Dz.U. z 2016 r. poz. 198.

6 A. Zybała, W gąszczu polityk publicznych, „Zeszyty Centrum Badań Społeczności i Polityk Lokalnych” 2010, nr 3, s. 6. Wskazane problemy dotyczą również samorządów terytorialnych, w których pojawiło się dodatkowo wiele dysfunkcji: etatystycznych, autokratycznych, biurokratycznych, finansowych, absorpcji środków unijnych, ułomnej wspólnotowości, przestrzennych oraz braku podmiotowości rozwojowej. Por. też J. Bober et al.., Narastające dysfunkcje, zasadnicze dylematy, konieczne działania. Raport o stanie samorządności terytorialnej w Polsce, Kraków 2013, s. 14. 
stu świadomości osób zaangażowanych w działania publiczne i skłonić je do zastosowania w praktyce wyników przeprowadzonych za pomocą metod naukowych analiz.

Badanie polityki publicznej i analiza działalności władz w kategoriach prowadzenia polityki publicznej zdobywa w Polsce coraz większą popularność (potwierdza to również wyodrębnienie jej jako dyscypliny naukowej). Problematyką tą zajmują się między innymi Grażyna Prawelska-Skrzypek, Barbara Kożuch (Instytut Spraw Publicznych Uniwersytetu Jagiellońskiego), dostępne są też opracowania: Jerzego Hausnera ${ }^{7}$, Stanisława Mazura ${ }^{8}$, Marcina Zawickiego 9 (Uniwersytet Ekonomiczny w Krakowie), Ryszarda Szarfenberga ${ }^{10}$ (Uniwersytet Warszawski), Andrzeja Zybały ${ }^{11}$ (Szkoła Główna Handlowa) czy innych. Wymienieni autorzy koncentrowali się głównie na zarządzaniu publicznym, teoretycznej analizie polityki publicznej lub jej elementów bądź też na analizie wybranych polityk szczegółowych. Wydaje się, że równie istotna jest analiza lokalnej polityki publicznej na poziomie samorządów terytorialnych, zwłaszcza pod kątem charakterystycznych uwarunkowań, które przesądzają o jej specyfice.

Ramy artykułu ograniczają możliwości szczegółowej analizy, stąd też skoncentrowano się na badaniu wpływu kontekstu sytuacyjnego ${ }^{12}$ na lokalną politykę publiczną prowadzoną przez gminy. Z konieczności pominięto inne, nie mniej istotne uwarunkowania, na przykład o charakterze zewnętrznym (m.in. narzucanie samorządom określonych rozwiązań przez administrację centralną czy też dostępność funduszy europejskich i związaną z nią możliwość podejmowania, nie zawsze racjonalnych, przedsięwzięć inwestycyjnych). Opierając się na podejściu Franka Fischera ${ }^{13}$, na potrzeby analizy kontekst sytuacyjny zdefiniowano jako zespół charakterystycznych uwarunkowań wewnętrznych, które łącznie tworzą określony stan faktyczny, uzasadniający (również w znaczeniu „umożliwiający”) podjęcie lub rezygnację z podjęcia publicznych działań. Sformułowano problem badawczy: jakiego rodzaju i jak duży wpływ na lokalną politykę publiczną wywierają specyficzne dla każdej jednostki samorządu terytorialnego uwarunkowania miejscowe?

Analizę przeprowadzono na podstawie źródeł zastanych, wykorzystując metodę analizy instytucjonalno-prawnej oraz analizy jakościowej. Przyjęto tezę, że kontekst sytuacyjny jako zbór wielowymiarowych miejscowych uwarunkowań odgrywa zasadniczą rolę w programowaniu lokalnej polityki publicznej.

7 J. Hausner, Polityka a polityka publiczna, „Zarządzanie Publiczne” 2007, nr 1.

8 S. Mazur, Założenia teoretyczne i metodologiczne nauk o polityce publicznej, „Wrocławskie Studia Politologiczne" 2015, nr 18.

9 Wprowadzenie do nauk o polityce publicznej, red. M. Zawicki, Warszawa 2013.

10 R. Szarfenberg, Nauki o i dla polityki publicznej: podejścia teoretyczno-metodologiczne, [w:] Analiza polityki publicznej. Podejścia teoretyczno-metodologiczne, red. A. Wojciuk, Warszawa 2013.

11 A. Zybała, Państwo i społeczeństwo w działaniu, Warszawa 2013.

12 W ogólnym ujęciu kontekst jest koncepcją relacyjną, jest zawsze kontekstem czegoś. Najszersze rozumienie kontekstu odnosi się do okoliczności, stosunków, sytuacji czy warunków, w jakich występuje badane zjawisko. Zob. J. Bielecka-Prus, Problem kontekstu w teoriach komunikowania społecznego, „Studia Socjologiczne" 2012, nr 1, s. 19.

${ }^{13}$ F. Fischer, Deliberative policy analysis as practical reason: Integrating empirical and normative arguments, [w:] Handbook of Public Policy. Analysis Theory, Politics, and Methods, red. F. Fischer, G.J. Miller, M.S. Sidney, Boca Raton-London-New York 2007. 


\section{Kontekst sytuacyjny jako element analizy polityki publicznej}

Polityka publiczna jest definiowana w różny sposób ${ }^{14}$. W szerokim ujęciu oznacza działania i programy publiczne, które są zracjonalizowane, oparte na zobiektywizowanej wiedzy, a ich projektowanie oraz wykonywanie odbywa się w ramach zamierzonej struktury. Integralną częścią polityki publicznej jest jej analiza ${ }^{15}$. Jedną z częściej przywoływanych, bardziej rozbudowanych, definicji jest ta sformułowana przez Brainarda Guya Petersa, który uważa politykę publiczną za działania (lub ich brak) wpływające na życie obywateli. Dotyczą one przyczyn i skutków realizowanych przez rządy programów. Analizę polityki publicznej ułatwia wyróżnienie przez B.G. Petersa jej trzech poziomów: 1) wyborów programowych, dokonywanych przez władze publiczne w celu wpłynięcia na życie obywateli; 2) realizacji programów publicznych przez aparat administracyjny i jego otoczenie oraz 3) rezultatów działań publicznych i ich wpływu na życie obywateli ${ }^{16}$.

Wyborom programowym odpowiada analiza i projektowanie polityki publicznej. Składają się na nią identyfikowanie i zdefiniowanie problemów, które wymagają rozwiązania, formułowanie kryteriów wyboru rozwiązań, tworzenie alternatywnych wariantów, opracowanie i prezentacja dokumentu polityki publicznej ${ }^{17}$. Podczas formułowania polityki publicznej pożądane jest, by opierano się na dowodach (a nie na opiniach), co zwiększa szanse podjęcia racjonalnej decyzji odnośnie do wyboru jej wariantu. Dojrzałe polityki publiczne wymagają docenienia wiedzy i wykorzystania jej w skali odpowiadającej złożoności problemów, które mają być rozwiązane ${ }^{18}$. Ponadto jej tworzenie nie powinno polegać jedynie na procesie stanowienia prawa. Pożądane jest, by było uzgodnione $\mathrm{w}$ toku deliberacji angażującej nie tylko decydentów, lecz także interesariuszy ${ }^{19}$.

Drugiemu poziomowi polityk publicznych - realizacji programów przez aparat administracyjny i jego otoczenie - odpowiada implementacja polityk, czyli ogół zaplanowanych i niezaplanowanych działań, które następują od momentu wyboru polityki publicznej planowanej do wdrożenia aż do uzyskania rezultatów tego wdrożenia ${ }^{20}$. Najczęściej wskazywane są trzy sposoby (perspektywy) wdrażania polityk publicznych: 1) odgórny - działania podejmowane są z pozycji najwyższych władz za pomocą głównego narzędzia - legislacji; 2) strategia oddolna - przyjmuje się, że dla powodzenia wdrożenia polityki publicznej istotne znaczenie ma wykorzystanie potencjału różnego

14 Zob. R. Chrabąszcz, M. Zawicki, Nauki o polityce publicznej, [w:] Wprowadzenie do nauk o polityce publicznej, red. M. Zawicki, Warszawa 2013, s. 17-18; A. Zybała, Państwo i społeczeństwo w działaniu. Polityki publiczne wobec potrzeb modernizacji państwa i społeczeństwa, Warszawa 2013, s. 41.

15 A. Zybała, Państwo i społeczeństwo..., s. 41.

16 B.G. Peters, American Public Policy. Promise and Performance, Washington 2004, s. 4-6.

17 S. Mazur, J. Górniak, Analiza i projektowanie polityk publicznych, [w:] M. Zawicki, op. cit., s. 41-65.

18 A. Zybała, Polityki publiczne, Warszawa 2012, http://ksap.gov.pl/ksap/sites/default/files/publikacje/ polityki_publiczne.pdf, s. 101 (dostęp: 8.04.2016).

19 A. Zybała, O lepsza jakość polityk publicznych, http://www.obserwatorkonstytucyjny.pl/publicystyka/o-lepsza-jakosc-polityk-publicznych/, s. 2-3 (dostęp: 8.06.2015).

${ }_{20}$ M. Zawicki, Implementacja polityk i programów publicznych, [w:] Zarzadzanie strategiczne rozwojem, red. J. Górniak, S. Mazur, Warszawa 2012, http://www.euroreg.uw.edu.pl/dane/web_euroreg_publications_ files/1210/zarzadzanie_strategiczne_rozwojem.pdf, s. 221 (dostęp: 8.04.2016). 
rodzaju podmiotów lokalnych (w tym lokalnych władz), które mogą i chcą uczestniczyć w rozwiązywaniu określonych problemów; 3) strategia syntezująca (hybrydowa) - łącząca wybrane metody obu wskazanych podejść 21 .

Trzeci poziom polityk publicznych w ujęciu Petersa - rezultaty wdrażania i ich wpływ na życie społeczeństwa - możliwe są do stwierdzenia w wyniku ewaluacji, czyli systematycznego badania prowadzonego z użyciem zróżnicowanych metod. Składa się na nie zbieranie danych, analiza, ocena oraz informowanie o wynikach. Celem jest oszacowanie (w odniesieniu do jasno sformułowanych kryteriów) jakości i wartości procesu oraz efektów wdrażania interwencji publicznych ${ }^{22}$.

Metody teoretyczno-metodologiczne stosowane w analizie polityk publicznych ewaluowały od podejścia racjonalistycznego do interpretatywnego. W pierwszym „polityka publiczna sprowadzona jest do zmatematyzowanego aktu wyboru jednego ze sposobów zmiany treści prawa lub szerzej instytucji" 23 . Analizowano ją głównie za pomocą metod ilościowych, oddzielano obiektywne fakty od wartości, a celem były konkluzje, które można było uogólnić niezależnie od kontekstu społecznego. Tego typu analizy poszerzały techniczną wiedzę o problemach dotykających społeczności, jednakże pojawiły się trudności z jej praktycznym zastosowaniem ${ }^{24}$. Drugim podejściem było podejście interpretatywne, w ramach którego w latach 90. XX wieku powstał nowy nurt, zwany przełomem argumentacyjnym. „Wiedza powinna stać się produktem interakcji - a nawet konfliktu - między konkurencyjnymi interpretacjami problemu publicznego" 25 . Naukowa akceptowalność wniosków nie zależy tylko od danych empirycznych, lecz także od innych czynników. Zebrane dane muszą być usytuowane w odpowiednim kontekście społecznym i sytuacyjnym, w ramach interpretacyjnych. Należy łączyć dane empiryczne z założeniami normatywnymi, według których porządkujemy rozumienie świata społecznego, sądami interpretacyjnymi ujawniającymi się w procesie zbierania danych, szczególnymi okolicznościami wynikającymi z kontekstu sytuacyjnego (w którym są pozyskiwane dane lub stosowane określone rozwiązania/zalecenia) oraz konkretnymi wnioskami ${ }^{26}$.

Analiza polityki publicznej według koncepcji Franka Fishera powinna zawierać cztery kluczowe komponenty:

1. badanie rezultatów i efektywności dokonywane za pomocą tradycyjnych narzędzi analitycznych w celu sprawdzenia, czy założone cele osiągnięto w najbardziej efektywny sposób;

2. badanie kontekstu sytuacyjnego, odpowiadające na pytania, czy przyjęte cele działania są istotne w sytuacji, w której mają być podjęte (czy sytuacja uzasadnia, lub też nie, podjęcie działań publicznych w danej sprawie);

21 A. Zybała, Państwo i społeczeństwo..., s. 267-269.

22 K. Olejniczak, Wprowadzenie do zagadnień ewaluacji, [w:] Teoria i praktyka ewaluacji interwencji publicznych, red. K. Olejniczak, M. Kozak, B. Ledziona, Warszawa 2008, s. 22.

23 R. Szarfenberg, Nauki o i dla polityki publicznej: podejścia teoretyczno-metodologiczne, https://www. academia.edu/4043672/Nauki_o_i_dla_polityki_publicznej_podej\%C5\%9Bcia_teoretyczno-metodologiczne, s. 20 (dostęp: 11.04.2016).

24 A. Zybała, Państwo i społeczeństwo..., s. 51.

25 Ibidem.

${ }^{26}$ F. Fischer, op. cit., s. 231. 
3. badanie kontekstu społecznego jako całości. Chodzi w nim o stwierdzenie, czy podjęte działania są wartością dla społeczeństwa, czy mieszczą się w jego modelu, czy dotyczą ważnych funkcji społecznych oraz jakie przyniosą konsekwencje, łącznie z oceną możliwości poradzenia sobie z tymi, które nie były zamierzone;

4. badanie wyborów ideologicznych i wartości społecznych polegające na analizie spójności założeń podejmowanych działań z wartościami społeczeństwa, badaniu podstaw decyzji dotyczących działań, zasad, na jakich mogą być rozstrzygane konflikty wartości i sprzeczne interesy. Powinny one dać odpowiedź, czy w sytuacji, gdy w ramach istniejącego porządku wartości nie można sprawiedliwie pogodzić istotnych interesów i potrzeb, możliwe jest przyjęcie alternatywnych zasad i wartości ${ }^{27}$.

Analiza polityki publicznej, według podejścia F. Fishera, wymaga uwzględnienia wszystkich czterech komponentów. Wydaje się jednak, że zarówno dla samej polityki, jak i dla jej analizy szczególnego znaczenia nabiera kontekst sytuacyjny. Na poziomie lokalnym nieco mniejszą rolę odgrywa kontekst społeczny z charakterystycznymi dla niego wyborami ideologicznymi i wartościami. Wynika to z faktu, że zdecydowana większość gmin obejmuje społeczności o stosunkowo jednorodnym systemie wartości ${ }^{28}$. Społeczność lokalną łączy nie tylko sieć instytucji, powiązania ekonomiczne i polityczne, działania lokalne i interakcje powstałe na ich podstawie, lecz także pewien ład moralny wyrosły na bazie wspólnego przebywania z sobą w miejscu zamieszkania ${ }^{29}$ oraz podzielanie tych samych wartości. Badanie rezultatów i efektywności jest oczywiście także ważne, lecz w pewnym sensie ma charakter „zamykający analizę”, gdyż dotyczy wyróżnionego przez Petersa trzeciego poziomu polityki publicznej - ewaluacji, która nawet w sytuacji zachowania systematyczności (i równoczesności) ma jednak charakter wtórny wobec etapów programowania i implementacji.

Kontekst sytuacyjny wpływa na interpretację wyników osiągniętych metodami konwencjonalnymi. Na poziomie lokalnym jest to szczególnie istotny element ze względu na to, że na tle państwa jednostki samorządu terytorialnego są niewielkie, mają małą bezwładność, co czyni je bardziej podatnymi na bodźce otoczenia zewnętrznego i różnorodne uwarunkowania wewnętrzne. W konsekwencji w tych samych warunkach prawnych, ekonomicznych, gospodarczych, a nawet ogólnospołecznych możliwości realizacji własnej polityki publicznej w poszczególnych jednostkach mogą się znacząco różnić.

\section{Wpływ kontekstu sytuacyjnego na politykę publiczną gmin}

Kontekst sytuacyjny wywiera największy wpływ na projektowanie lokalnej polityki. Jak już wspomniano, samorządy terytorialne nie dysponują takim zakresem samodzielności jak państwo (administracja centralna), stąd też możliwości programowania własnej

27 Za: A. Zybała, Państwo i społeczeństwo..., s. 55-56.

28 Istotnym czynnikiem jest znowu wielkość jednostek terytorialnych. W 2014 roku spośród 2479 gmin prawie 1600 (ok. 65\%) liczyło poniżej 10 tys. mieszkańców. Por. Główny Urząd Statystyczny, Powierzchnia i ludność w przekroju terytorialnym w 2014 r., Warszawa 2014, s. 46.

29 B. Lewenstein, Wspólnota społeczna a uczestnictwo lokalne, Warszawa 1999, s. 13. 
polityki publicznej z natury rzeczy są ograniczone. Ograniczenia nie oznaczają jednak ubezwłasnowolnienia.

Gminy realizują zadania obowiązkowe i fakultatywne. Ma to wpływ na agendę lokalnej polityki publicznej ${ }^{30}$. W przypadku zadań obowiązkowych władze lokalne muszą się zajmować danym obszarem życia publicznego. Nie oznacza to jednak, że agenda jest całkowicie określona, bo w ramach tego obszaru istnieje wiele problemów, którym należy nadać odpowiednią wagę i zdecydować, wobec których będą podjęte działania. Uwarunkowania kontekstowe stają się niezwykle ważne. To miejscowe okoliczności wpływają na dokonanie wyboru. Część z nich ma charakter obiektywny (np. warunki geograficzno-przyrodnicze, potencjał ludnościowy, poziom rozwoju gospodarczego, stan infrastruktury, wielkość subwencji ${ }^{31}$ ), część zaś zależy od subiektywnej oceny istniejącego i pożądanego stanu, mającej źródło w wyznawanym systemie wartości i sposobie postrzegania otaczającej rzeczywistości, składowych kontekstu społecznego.

Kontekst sytuacyjny dotyczy różnych kwestii. Ze względów analitycznych wskazane jest wyróżnienie tych, których występowanie ma charakter powszechny niezależnie od miejscowych warunków i które istotnie wpływają na proces programowania lokalnej polityki publicznej.

Tabela 1. Wymiary kontekstu sytuacyjnego w programowaniu lokalnej polityki publicznej

\begin{tabular}{l|l}
\hline Wymiar kontekstu & \multicolumn{1}{|c}{ Uwarunkowania - cechy } \\
\hline \multirow{4}{*}{ Ekonomiczny } & Wielkość dochodów i możliwości ich zwiększenia \\
\cline { 2 - 2 } & Zadłużenie, możliwości zaciągnięcia nowych zobowiązań finansowych \\
\cline { 2 - 2 } & Poziom stałych wydatków bieżących i możliwości ich ograniczenia \\
\cline { 2 - 2 } & Poziom ogólnego rozwoju gospodarczego \\
\cline { 2 - 2 } & Stan infrastruktury technicznej \\
\hline \multirow{4}{*}{ Relacyjny } & Lokalny ład społeczny, stan więzi społecznych \\
\cline { 2 - 2 } & Poziom zaufania (wzajemnego mieszkańców i do władz lokalnych) \\
\cline { 2 - 2 } & Jakość społeczeństwa obywatelskiego, aktywność publiczna mieszkańców \\
\cline { 2 - 2 } & Występowanie, nasilenie i sposób rozwiązywania konfliktów \\
\hline \multirow{5}{*}{ Organizacyjny } & Układ sił politycznych we władzach lokalnych \\
\cline { 2 - 2 } & Styl podejmowania decyzji \\
\cline { 2 - 2 } & Aktywność polityczna mieszkańców \\
\hline & Istniejące jednostki organizacyjne i ich potencjał \\
\cline { 2 - 2 } & Jakość zasobów kadrowych \\
\cline { 2 - 2 } & Styl zarządzania gminą i jednostkami organizacyjnymi \\
\hline
\end{tabular}

Źródło: Opracowanie własne.

30 Agenda to proces, $w$ którym jakiemuś problemowi publicznemu nadaje się znaczenie i miejsce w hierarchii ważności. Nie każdy wyartykułowany problem staje się automatycznie przedmiotem polityki publicznej. Władze muszą dokonać wyboru, podjąć decyzję, czym w danym momencie się zajmą.

31 W dłuższej perspektywie społeczność lokalna ma wpływ na poziom rozwoju gospodarczego, stan infrastruktury, a nawet pośrednio na wielkość subwencji z budżetu państwa, jednak w chwili podejmowania rozstrzygnięcia uczestnicy procesu decyzyjnego mają do czynienia z konkretnym stanem zastanym i w tym znaczeniu są to warunki obiektywne. 
Niezależnie od wyróżnienia poszczególnych wymiarów kontekstu sytuacyjnego analizę każdego z nich należy prowadzić w relacji do pozostałych. To właśnie lokalna specyfika każdego z wymiarów oddziałuje na sposób postrzegania polityki publicznej i na jej ocenę.

W zasadzie każde działanie w sferze publicznej wiąże się z koniecznością poniesienia jakichś nakładów finansowych. Z tego powodu ekonomiczny wymiar kontekstu lokalnej (i nie tylko) polityki publicznej jest bardzo istotny. Wpływa on zarówno na decyzję, czy zidentyfikowany (wyartykułowany) problem znajdzie się w ogóle w agendzie działań władz gminy, jak i na to, jak będzie wyglądała interwencja w sytuacji, gdy działania zostaną podjęte. W praktyce sprowadza się to do udzielenia odpowiedzi na pytanie: „czy nas na to stać? lub „na co (na jaki zakres) nas stać”? Odpowiedzi będą zróżnicowane, tak jak zróżnicowana jest sytuacja ekonomiczna poszczególnych gmin. Istotnie wpływa na nią przede wszystkim poziom ich dochodów, a ten nie jest jednakowy. W bezpośrednim zestawieniu różnice dochodów w przeliczeniu na jednego mieszkańca w poszczególnych gminach mogą sięgać nawet kilkudziesięciu procent ${ }^{32}$. Sytuacja ekonomiczna gmin zależy od wielu czynników. Jako przykład można wskazać profil gminy (rolniczy, przemysłowy, mieszkaniowy, turystyczny usługowy oraz bez wyraźnego profilu) ${ }^{33}$ lub też szczegółowe typy polityk lokalnych (przedsiębiorczości, równoważenia rozwoju wielu dziedzin, redystrybucji i rozwoju infrastruktury społecznej) ${ }^{34}$ oraz związane z nimi możliwości generowania dochodów własnych. Poza wykazanymi różnicami nie mniej istotne są pozostałe, wymienione w tabeli 1, kryteria/cechy ekonomicznego wymiaru uwarunkowań kontekstowych.

$\mathrm{Na}$ istniejącą w danym momencie ogólną sytuację ekonomiczną nakładają się pozostałe wymiary kontekstu sytuacyjnego, odgrywające ważną rolę na poziomie programowania lokalnej polityki publicznej. Ściśle związane z sobą są dwa: relacyjny i polityczny. Wobec ograniczonych zasobów o charakterze ekonomicznym, z którymi mamy do czynienia praktycznie w każdej sytuacji, gdyż oczekiwania społeczne ciągle rosną i wyprzedzają faktyczne możliwości, konieczne jest dokonywanie wyborów. W przypadku polityki publicznej sprowadza się ono do określenia agendy działań. W poszczególnych gminach wybór działań może odbywać się według odmiennych stylów, a wpływ na to mają przede wszystkim: jakość społeczeństwa obywatelskiego, preferencje społeczności lokalnej oraz styl podejmowania decyzji.

Tworzenie polityki publicznej nie powinno sprowadzać się jedynie do procesu stanowienia prawa, a w przypadku samorządu gminnego - podejmowania decyzji przez lokalne władze. Jak już wspomniano we wprowadzeniu, pożądane jest jej uzgadnianie w toku deliberacji angażującej nie tylko decydentów, lecz także interesariuszy (mieszkańców). To, czy do takich uzgodnień dochodzi, zależy zarówno od aktywności mieszkańców, jak i od nastawienia władz lokalnych oraz stylu podejmowania przez nie decyzji. Procedura deliberacji wymaga „neutralności” ośrodków władzy, możliwie szerokiego

32 W 2013 roku w województwie podkarpackim różnica w dochodach per capita między gminą Przeworsk (2365 zł) a Stary Dzików (3775 zł) wyniosła blisko 40\%. Por. A. Czudec, Gospodarka finansowa jednostek samorzadu terytorialnego na Podkarpaciu w 2013 roku, „Budżet Samorządu Terytorialnego” 2015, nr 21, s. 103.

33 J. Pasieczny, Profile gmin w Polsce - zarzadzanie rozwojem i zmianami, Warszawa 2008, s. 167-228.

34 G. Masik, Typy polityki lokalnej. Przykład strefy suburbanizacji aglomeracji Trójmiasta, „Studia Regionalne i Lokalne" 2010, nr 1, s. 43. 
dostępu zainteresowanych podmiotów społeczeństwa obywatelskiego do deliberacyjnych sieci, powinna przynosić wymierne efekty, oznacza równy dostęp do głosu oraz ekwiwalencję angażowanych zasobó $w^{35}$. W polskich realiach trudno odnaleźć takie modelowe przykłady deliberacji. Na obecnym etapie rozwoju demokracji na poziomie gmin można raczej mówić o partycypacji społecznej, która z różnym nasileniem pojawia się w poszczególnych jednostkach. Jednak, jak wskazują badania, władze lokalne nie cenią partycypacji publicznej; samodzielnie podejmują decyzje i informują o nich mieszkańców, ewentualnie poprzedzając je konsultacjami, które często mają jedynie formalny charakter $^{36}$. Ogólnie zła ocena stosunku władz lokalnych do partycypacji społecznej nie wyklucza jednak różnic pomiędzy poszczególnymi jednostkami. To właśnie one tworzą lokalny kontekst sytuacyjny, który powoduje odmienność stylów programowania lokalnych polityk publicznych. W niektórych gminach korzystanie z instrumentów partycypacyjnych wpływa na cele polityki publicznej, które nie tylko uwzględniają preferencje większości, lecz także „szanują” odmienne zdanie mniejszości ${ }^{37}$. W innych programowanie ogranicza się do arbitralnych decyzji władz lokalnych. Czasami sprzyja temu niski poziom zaangażowania mieszkańców w sprawy publiczne ${ }^{38}$.

Na programowanie lokalnej polityki publicznej wpływa też organizacyjny wymiar kontekstu sytuacyjnego. Zaprogramowaną politykę musi ktoś implementować, stąd też już na etapie planowania należy dokonać oceny, czy osiągnięcie celów będzie możliwe w określonym stanie organizacyjnym jednostki. Istniejące przepisy, dzięki którym gminy dysponują prawem określania swojego ustroju wewnętrznego oraz prawem powoływania jednostek organizacyjnych do realizacji zadań lub zlecania pewnych działań podmiotom zewnętrznym, niejako automatycznie powodują różnice organizacyjne pomiędzy gminami. Każda $\mathrm{z}$ nich przyjmuje własną strukturę organizacyjną sprzyjającą bądź utrudniającą realizację szczegółowych polityk publicznych.

$\mathrm{Na}$ przykład na realizację przez gminy polityki oświatowej wpływa między innymi liczba prowadzonych szkół, oddziałów szkolnych, poziom kompetencji kadry pedagogicznej i zarządzającej. Na politykę kulturalną wpływa to, czy biblioteka publiczna funkcjonuje jako jednostka samodzielna, czy też razem z ośrodkiem kultury ${ }^{39}$. Poziom kompetencji urzędników warunkuje możliwości realizacji skomplikowanych przedsięwzięć. Tego typu zależności jest wiele. Należy jednak mieć na uwadze, że kwestie organizacyjne

35 J. Sroka, Deliberacja i rzadzenie wielopasmowe. Teoria i praktyka, Wrocław 2009, s. 41-42.

36 A. Olech, P. Sobiesiak-Penszko, Partycypacja publiczna w Polsce. Diagnoza i rekomendacje, „Analizy i Opinie" 2013, nr 3.

37 Istnieją pozytywne przykłady partycypacji mieszkańców w procesach decyzyjnych. Zob. W60 praktyk dookoła partycypacji, red. O. Chrzanowski et al., Warszawa 2014; Baza dobrych praktyk, Fundacja Inicjatyw Społeczno-Ekonomicznych, http://partycypacja.fise.org.pl/ (dostęp: 11.04.2015).

38 Jest to niekorzystne. Jak wykazały badania na próbie 1030 polskich gmin, te jednostki, w których poziom mobilizacji społecznej jest wyższy, osiągają lepsze tempo rozwoju. Por. J.T. Hryniewicz, Polityczny i kulturowy kontekst rozwoju gospodarczego, Warszawa 2004, s. 67.

39 Prawnie takie rozwiązanie jest dopuszczalne, lecz niekorzystne - zwykle taka jednostka koncentruje się na jednym obszarze, drugi traktując jako działalność dodatkową. Por. B. Kotarba, Miejsce młodzieży w polityce społecznej gmin, [w:] Od kwestii robotniczej do nowoczesnej kwestii socjalnej. Studia z polskiej polityki społecznej XX i XXI wieku, red. P. Grata, Rzeszów 2014, s. 176. 
nie funkcjonują w oderwaniu od pozostałych wymiarów kontekstu sytuacyjnego. Stąd też niemożliwe jest osiągnięcie jednakowego czy nawet porównywalnego potencjału organizacyjnego gmin. Programowanie polityk szczegółowych powinno opierać się na istniejącym stanie organizacyjnym, $\mathrm{z}$ uwzględnieniem możliwych do wprowadzenia korekt, sprzyjających osiągnięciu założonych celów.

\section{Podsumowanie}

Polityka publiczna jest realizowana na różnych poziomach władzy publicznej. Wśród podmiotów zaangażowanych $\mathrm{w}$ jej uprawianie ważną rolę odgrywają jednostki samorządu terytorialnego, zwłaszcza gminy, gdyż zaspokajają wiele zbiorowych potrzeb mieszkańców, często o znaczeniu podstawowym. Jednak gminy nie są podmiotami jednorodnymi. Występują między nimi znaczące różnice potencjałów, co powoduje, że w tych samych warunkach instytucjonalno-prawnych mają odmienne możliwości realizacji „własnej”, lokalnej polityki publicznej. Różnice te stanowią specyficzny dla nich kontekst sytuacyjny. Ma on kilka wymiarów: ekonomiczny, społeczny, polityczny, organizacyjny. Jak wykazała przeprowadzona analiza, kontekst sytuacyjny ma istotne znaczenie dla realizacji lokalnej polityki publicznej, zwłaszcza na etapie jej programowania. To lokalne uwarunkowania determinują możliwość podjęcia określonych działań przez władze samorządowe, ich zakres, jak również sposób wyznaczania/uzgadniania celów. Odpowiedzialne kreowanie lokalnej polityki publicznej, podobnie jak obiektywna i rzetelna ocena jej realizacji, wymagają uwzględnienia kontekstu sytuacyjnego.

\section{Bibliografia}

Bielecka-Prus J., Problem kontekstu w teoriach komunikowani społecznego, „Studia Socjologiczne” 2012, nr 1.

Bober J. et al., Narastajace dysfunkcje, zasadnicze dylematy, konieczne działania. Raport o stanie samorzadności terytorialnej w Polsce, Uniwersytet Ekonomiczny, Małopolska Szkoła Administracji Publicznej, Kraków 2013.

Chrabąszcz R., Zawicki M., Nauki o polityce publicznej, [w:] Wprowadzenie do nauk o polityce publicznej, red. M. Zawicki, Polskie Wydawnictwo Ekonomiczne, Warszawa 2013.

Czudec A., Gospodarka finansowa jednostek samorządu terytorialnego na Podkarpaciu w 2013 roku, „Budżet Samorządu Terytorialnego" 2015, nr 21.

Fischer F., Deliberative policy analysis as practical reason: Integrating empirical and normative arguments, [w:] Handbook of Public Policy. Analysis Theory, Politics, and Methods, red. F. Fischer, G.J. Miller, M.S. Sidney, CRC Press, Boca Raton-London-New York 2007.

Hryniewicz J.T., Polityczny i kulturowy kontekst rozwoju gospodarczego, Scholar, Warszawa 2004.

Konstytucja Rzeczypospolitej Polskiej z dnia 2 kwietnia 1997 r., Dz.U. Nr 78, poz. 483 z późn. zm.

Kotarba B., Miejsce młodzieży w polityce społecznej gmin, [w:] Od kwestii robotniczej do nowoczesnej kwestii socjalnej. Studia z polskiej polityki społecznej XX i XXI wieku, red. P. Grata, Wydawnictwo Uniwersytetu Rzeszowskiego, Rzeszów 2014.

Kotarba B., The implementation of public policies by the local govermnments: education policy, [w:] New Public Governance in the Visegrád Group (V4), red. R. Wiszniowski, K. Glinka, Wydawnictwo Adam Marszałek, Toruń 2015. 
Lewenstein B., Wspólnota społeczna a uczestnictwo lokalne, Instytut Stosowanych Nauk Społecznych. Uniwersytet Warszawski, Warszawa 1999.

Masik G., Typy polityki lokalnej. Przykład strefy suburbanizacji aglomeracji Trójmiasta, „Studia Regionalne i Lokalne" 2010, nr 1.

Mazur S., Górniak J., Analiza i projektowanie polityk publicznych, [w:] Wprowadzenie do nauk o polityce publicznej, red. M. Zawicki, Polskie Wydawnictwo Ekonomiczne, Warszawa 2013.

Olech A., Sobiesiak-Penszko P., Partycypacja publiczna w Polsce. Diagnoza i rekomendacje, „Analizy i Opinie" 2013, nr 3.

Olejniczak K., Wprowadzenie do zagadnień ewaluacji, [w:] Teoria i praktyka ewaluacji interwencji publicznych, red. K. Olejniczak, M. Kozak, B. Ledziona, Wydawnictwa Akademickie i Profesjonalne, Akademia Leona Koźmińskiego, Warszawa 2008.

Pasieczny J., Profile gmin w Polsce - zarządzanie rozwojem i zmianami, Wydawnictwo Naukowe Wydziału Zarządzania Uniwersytetu Warszawskiego, Warszawa 2008.

Peters B.G., American Public Policy. Promise and Performance, CQ Press, Washington 2004.

Powierzchnia i ludność w przekroju terytorialnym w 2014 r., Główny Urząd Statystyczny, Warszawa 2014.

Sroka J., Deliberacja i rzadzenie wielopasmowe. Teoria i praktyka, Wydawnictwo Uniwersytetu Wrocławskiego, Wrocław 2009.

Ustawa z dnia 13 listopada 2003 r. o dochodach jednostek samorządu terytorialnego, tekst jednolity Dz.U. z 2016 r. poz. 198.

Ustawa z dnia 8 marca 1990 r. o samorządzie gminnym, tekst jednolity Dz.U. z 2016 r. poz. 446.

Ustawa z dnia 29 sierpnia 2009 r. o finansach publicznych, tekst jednolity Dz.U. z 2013 r. poz. 885.

W 60 praktyk dookoła partycypacji, red. O. Chrzanowski et al., Fundacja Inicjatyw Społeczno-Ekonomicznych, Warszawa 2014.

Zybała A., Państwo i społeczeństwo w działaniu. Polityki publiczne wobec potrzeb modernizacji państwa i spoŁeczeństwa, Difin, Warszawa 2013.

Zybała A., W gąszczu polityk publicznych, „Zeszyty Centrum Badań Społeczności i Polityk Lokalnych” 2010, nr 3.

\section{Źródła internetowe}

Baza dobrych praktyk, Fundacja Inicjatyw Społeczno-Ekonomicznych, http://partycypacja.fise.org.pl/.

Szarfenberg R., Nauki o i dla polityki publicznej: podejścia teoretyczno-metodologiczne, https://www.academia. edu/4043672/Nauki_o_i_dla_polityki_publicznej_podej\%C5\%9Bcia_teoretyczno-metodologiczne.

Zawicki M., Implementacja polityk i programów publicznych, [w:], Zarządzanie strategiczne rozwojem, red. J. Górniak, S. Mazur, Ministerstwo Rozwoju Regionalnego, Warszawa 2012, http://www.euroreg. uw.edu.pl/dane/web_euroreg_publications_files/1210/zarzadzanie_strategiczne_rozwojem.pdf.

Zybała A., O lepsza jakość polityk publicznych, http://www.obserwatorkonstytucyjny.pl/publicystyka/o-lepsza-jakosc-polityk-publicznych/.

Zybała A., Polityki publiczne, Krajowa Szkoła Administracji Publicznej, Warszawa 2012, http://ksap.gov.pl/ ksap/sites/default/files/publikacje/polityki_publiczne.pdf. 


\section{The meaning of situational context in public policy at the local level}

Keywords: comune, local public policy, programming of public policy, situational context

\section{Summary}

Public policy is carried out at various levels of public authority. Among the entities involved in its implementation an important role is played by local government units, especially communes. The differentiation of the potentials of communes is the reason why in the same legal and institutional conditions various communes have different possibilities for the realization of their "own" public policy. These differences constitute a situational context, characteristic for each commune. The article analyzes the impact of this context on one of the levels of public policy set apart by B.G. Peters - programming. The thesis: Situational context seen as a set of multi-dimensional local determinants plays a key role in the programming of local public policies has been adopted and verified positively. 